\title{
Impact of the mentoring relationship on the development of talented students - a narrative review
}

\author{
Tina Vrabie•, Carmen Mihaela Crețu•
}

\section{Abstract}

In order to provide quality instruction for students, to cultivate free and entrepreneurial spirits, the educational system needs teachers capable of acting as mentors for their students; inspiring them, teaching them about moral values and helping them develop their cognitive and career-orientation skills. Through the impact that it has on the development of students in general and on the talented students in particular, mentoring is one of the most appropriate strategies for achieving this goal.

This article is a narrative review of the studies identified in the literature that describe a series of mentoring programs especially designed for talented students, which have contributed to their development on the psychosocial and cognitive level, as well as on career orientation. Complete research articles related to mentoring programs for talented students were gathered from online database searches and needed to meet several criteria: (1) the program evaluated needed to involve mentoring as the practice has been defined like an "ideal type" of mentoring in the literature (Grassinger, Porath, \& Ziegler, 2010); (2) the study had to examine the impact of involvement in a mentoring program on the development of talented students on several levels: psychosocial, cognitive, career support; and (3) the sample used in the evaluation of the program needed to include the talented students that are more predisposed to benefit from a mentoring program: talented primary, gymnasium and high school students and twice-exceptional students (Goff \& Torrance, 1999; Subotnik, Olszewski-Kubilius, Khalid, \& Finster, 2021).

The results of this review underline the impact of the talented students' involvement in a mentoring relationship on their development and the necessity for this type of programs to be sustained in an educational context, not only at an informal level but also through formal programs specifically designed and implemented for this purpose.

The paper concludes by presenting a series of recommendations on how such programs can be effectively implemented at the educational institutions level.

Keywords: mentoring, development, talented students

\footnotetext{
- Tina Vrabie - PhD Student, Doctoral School of Faculty of Psychology and Education Sciences, "Alexandru Ioan Cuza" University of Iasi, Romania, e-mail: turiceanutina@yahoo.com

- Carmen Mihaela Crețu - Professor, Ph.D., Psychology Education Sciences, Faculty of Psychology and Education Sciences, “Alexandru Ioan Cuza” University of Iasi
} 


\section{Introduction}

Since the talented students have a series of special characteristics and specific needs that require specialized educational interventions, it is absolutely necessary that they will "be able to benefit from appropriate educational conditions that would allow them to develop fully their abilities, for their own benefit and for the benefit of society as a whole. No country can indeed afford to waste talents and it would be a waste of human resources not to identify in good time any intellectual or other potentialities. Adequate tools are needed for this purpose." (Council of Europe, Recommendation 1248, 1994). At the same time, the gap between the cognitive development and the affective development of talented students determines certain difficulties that this category of learners faces, as follows: situations of school underachievement and isolation, as well as blockages that they can manifest in the communication with those around them, intellectual inhibitions, and depressive states.

In general, regarding talented students, there are certain expectations that they are able to solve tasks they receive in the school context without designing these tasks according to their specific learning rhythm and special learning needs. Although in most cases this is the only option considered for teaching talented students, several alternatives are being used more and more often in order to maximize their potential. One of these is definitely mentoring.

The idea that talented students do not need support or minimal assistance in developing their talents is one of the most common misconceptions in the field of gifted education, many people believing that they learn anything easily, due to their high level of intelligence (Ambrose, Allen \& Huntley, 1994). Moreover, many studies also demonstrate that most talented students get bored during classes, because of the lack of challenges received in educational contexts. Based on these results, mentoring is considered to be a good approach to providing talented students with the challenges and academic rigor that they need. By becoming involved in a mentoring relationship they also have the opportunity to explore their potential and inclination towards certain careers, to apply the knowledge gained during classes, to mature and to have a human/professional model to follow (Berger, 1990 as cited in Bisland, 2001).

According to Kay and Hinds, mentoring "is a relationship between two people, amongst which there is no managerial relationship (of the chief-subaltern type), in which one person (the mentor) guides the other (the mentee) in a period of change, taking into account a number of previously established objectives" (Kay \& Hinds, 2002, p. 28).

The purpose of mentoring, in the didactic context, is to help students to assimilate a series of contents and information, to which they don't have access in the traditional education system, as well as to guide students in the process of identifying the diversity of career opportunities which they have. At the same time, the most common use of the concept of mentoring involves a "teaching-learning" relationship, during which an experienced person can help a mentee - a posture in which the student is usually placed 
- to achieve major professional goals or to properly develop his or her learning potential (Manning, 2005).

In the last decade, mentoring programs have received considerable attention as educational interventions for students with different academic, behavioral and social needs. Therefore mentoring is recognized as a strategy of providing guidance to all categories of students, including talented students; being a proper way to train, support and counsel them in order to satisfy their specific learning and development needs (Clasen \& Clasen, 2003).

\section{The Benefits of Mentoring in Working with Talented Students}

In the gifted education literature, it is mentioned that mentoring programs are useful especially for talented students who have exhausted all sources and learning resources available in the school educational context, as well as for talented students that are facing school underachievement or for talented students from disadvantaged backgrounds, who are unaware of their own potential and are incapable of using it without specific interventions (Goff \& Torrance, 1999). Therefore, mentoring has a considerable influence on the academic achievement of talented students, in the development of their specialized knowledge, as well as in the process of transforming them into specialists and remarkable exponents of their fields of interest.

At the same time, mentoring activities can play a significant role in supporting talented students in meeting their emotional and social interaction needs. Research in the field (Casey, 1997) suggests that talented students have a variety of affective characteristics and, on many occasions, face feelings of social isolation and dissatisfaction due to their poor interpersonal relationships. Also, increased sensitivity and perfectionism are other defining features regularly experienced by talented students. In this regard, mentors can serve as a model for the talented students, supporting them in managing the problems they face because of their special characteristics and providing the emotional support that they need.

In the organizational context, there are two types of support that mentors give to those they guide: psychosocial support and career support. Psychosocial support consists in sharing experiences, transfer of values, moral support and the establishment of a friendly relationship with the mentor. Career support refers to activities such as coaching, as well as to identifying opportunities for career development and setting up the pathways for accessing these opportunities, scholarships and sponsorships in the field of career development, and the challenges that mentees are likely to face in the field (Kram, 1985).

Relevant literature in the field of gifted education suggests that mentoring programs that target talented students in educational context offer both psychosocial support and career support (Lunsford, 2011). Mentoring programs for talented students may be formal or informal. 
One of the most common mentoring relationships is set at an informal level between teacher and students. The model provided daily by the teacher, in terms of valorizing education and learning activities, has the role of encouraging students for learning throughout their life. Also, students often ask their teachers for advice, guidance, and learning support (Bisland, 2001).

Formal mentoring programs for talented students in primary school, secondary school and high school are organized according to a well-established plan and are aimed at objectives that imply: accelerated learning and providing additional information to talented students about their areas of interest; career orientation; developing and training the social skills of talented young people (Wright - Romjue, 1991).

According to these considerations, we can say that there are a number of reasons why talented students can be considered the ideal subjects for participation in mentoring programs. First of all, it is necessary to mention that the intervention of an adult is essential in the process of developing the learning potential of a talented student. Therefore, mentors who are experts in a particular field of activity can inspire, challenge and encourage talented students to maximize their potential.

Also, according to a study conducted by Carmen Cretu and Nicoleta Rogoz (2016), talented students feel the need to participate in mentoring activities and consider that these are extremely important for their academic and professional career.

Other research in the field also demonstrates that both formal and informal mentoring activities and experiences can represent opportunities for talented students to explore their options regarding the career that they want to choose or follow (Bloom, 1985 as cited in Casey, 1997, p. 14,Lunsford, 2011). In this kind of activities, mentors have the opportunity to inform talented students about the lifestyle and the educational needs associated with a particular career path, in order to help them figure out if they have the skills and the abilities needed to follow it.

Many of the papers in the field of gifted education also mention that talented students interact more successfully with adults due to their superior cognitive and affective capacity (Casey, 1997). A study conducted by Buescher in 1991 stated that usually talented students have an increased capacity to establish relationships with adults, as well as the ability to learn from them. According to Reis and Follo (1993), talented students are good candidates for acceptance in mentoring programs also because of their ability to work independently, as well as because of their high level of engagement and motivation for learning activities, which they show at the highest levels (Reis\&Follo, 1993 as cited in Casey, 1997). Also, they prefer independent study; during classroom courses they choose individual learning activities rather than teamwork, pairing or grouping. Therefore, mentoring activities meet the needs of talented students; the mentor spends many hours with the "mentee" on a working day just to satisfy the desire to acquire knowledge in his or her area of interest, as well as to satisfy his or her wish to invest time and cognitive resources to develop the talent and potential he or she has. 
In the following, we will present a series of studies from the literature on the impact of the mentoring relationship on the development of talented students/ students with high abilities.

\section{Mentoring Relationship and Development of Talented Students}

In the scientific literature in the field of gifted education there is ambiguity in the distinction between the concepts of giftedness and talent and there is no consensus on what this terms mean. In general usage, and also in dictionary usage and scientific articles, no definite distinction is made between the ideas of giftedness and talent (Gagné, 1985). This ambiguity is supported by the various and sometimes divergent definitions of the concepts (McBee, \& Makel, 2019) and by randomly using one or the other term in the same paragraph, thus suggesting that they are synonyms (Gagné, 1985). The same problem is also noted in terms of identifying these students and including them in special gifted education programs, like mentoring programs. These programs address, depending on their typology, more categories of students in the field of gifted education: talented students, high achieving students and identified gifted students. Because of the various definitions of these concepts, students who are likely to benefit from gifted services are not always identified using this approach (Ritchotte, Suhr, Alfurayh, \& Graefe, 2016). This is why, as you will see, the mentoring programs that we included in our analysis are designed for all these three categories of students, depending on the criteria that are used for their inclusion in the group of beneficiaries.

Unfortunately, the concept of mentoring also does not have a unanimously accepted definition in the literature and "tends to be one of those notorious "toothbrush" concepts: every researcher has their own definition, a definition that is practically never used by colleagues. Consequently, the current research landscape is characterized more by separate paths than any fruitful, common efforts." (Grassinger, Porath, \& Ziegler, 2010, p. 27). As well, there is a considerable diversity that has characterized intervention efforts in the mentoring area and an impressive number of different mentoring programs, which vary by: their basic goals, their philosophy, the procedures used for recruiting prospective mentors and the levels of training and supervision that are provided to mentors once selected (DuBois, Holloway, Valentine, \& Cooper, 2002). This is why we cannot provide a uniform definition for the mentoring programs addressing talented students but only a definition of what should be the "ideal type" of mentoring: Mentoring of gifted individuals is a relatively chronologically stable dyadic relationship between an experienced mentor and a less experienced gifted mentee, characterized by mutual trust and benevolence, with the purpose of promoting learning, development, and, ultimately, progress in the mentee (Grassinger, Porath, \& Ziegler, 2010, p. 30).

Mentoring programs for talented students, described in the literature, are also quite diverse; in terms of organization and from the point of view of the objectives they aim to support talented students in their own process of development. In this regard, we made a synthesis of the research that focuses on highlighting the impact of involvement in a 
mentoring program on the development of talented students on several levels: academic, cognitive (intellectual) \& creative, psychosocial, socioemotional or affective, career or vocational support (DuBois, Holloway, Valentine, \& Cooper, 2002; Burton, 2012).

\section{Method}

Although mentoring is considered among the most effective pedagogical measures, it is rarely used in gifted education (Grassinger, Porath, \& Ziegler, 2010). This is why there is no systematic approach to mentoring activities in the field of gifted education. Mentoring programs for talented students are also very different depending on: the age of the students that benefit from them; their school level/developmental level; thematic areas, goals and the philosophy of the mentoring program (Subotnik, Olszewski-Kubilius, Khalid, \& Finster, 2021). However, a large amount of research in the field of mentoring suggests its positive effects in the lives of successful people and have shown that most of them have participated in mentoring programs in adolescence and youth, fact that helped them to achieve exceptional results in different areas (Bloom, 1985; Kaufman, Harrel, Milam, Woolverton \& Miller, 1986; Roche, 1979; Torrance, 1984; Vaillant, 1977; Mammadov \& Topōu, 2014). Based on this, we formulate our research question: How has the relationship between mentoring programs and their impact on the development of talented students been addressed in the literature?

We conducted the literature searches in the Google Scholar and in the following electronic databases: Web of Science, Dissertation Abstracts reference database ProQuest and ERIH PLUS. Search terms related to gifted education (gifted students, talented students, students with high potential) were combined with search terms related to mentoring (mentor, mentee relationship, protégée) to identify relevant articles and dissertations. Keywords and their variants were used as appropriate for each database. The reference lists of relevant studies were screened to identify additional articles. Articles were considered for inclusion if they were published in English, in a scientific journal, between 1990 when, as far as we know, research on the outcomes of mentoring programs in gifted education began to appear, to 2020. To be included in the present narrative review studies needed to meet several criteria. First, the program evaluated needed to involve mentoring as the practice has been defined like an "ideal type" of mentoring in the literature (Grassinger, Porath, \& Ziegler, 2010). Second, the study had to examine the impact of involvement in a mentoring program on the development of talented students on several levels: psychosocial, cognitive, career support. Finally, the sample used in the evaluation of the program needed to include the talented students that are more predisposed to benefit from a mentoring program: talented primary, gymnasium and high school students and twice-exceptional students (Goff \& Torrance, 1999; Subotnik, Olszewski-Kubilius, Khalid, \& Finster, 2021). After deduplicating the search results from different databases, articles underwent two rounds of screening based on their (1) title and abstract and (2) full text. For the papers that met our inclusion criteria (19), we extracted the following data: authors, year of publication, method used 
to measure the impact of mentoring programs on the development of talented students, the results obtained. The extracted data were then analyzed, and the findings were organized into a table that presents different Mentoring Programs for Talented Students and their impact on the development of talented students on several levels: academic, cognitive (intellectual) \& creative, psychosocial, socioemotional or affective, career or vocational support (Table 1). 


\begin{tabular}{|c|c|c|c|c|c|}
\hline \multirow{5}{*}{ 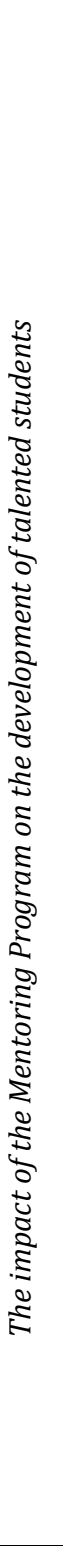 } & & Study \& year & $\begin{array}{l}\text { Title and Location of the Mentoring } \\
\text { Programs }\end{array}$ & $\begin{array}{c}\text { Method } \\
\& \\
\text { Number of subjects }\end{array}$ & Results \\
\hline & \multirow{4}{*}{$\begin{array}{l}\text { Academic, Cognitive } \\
\text { (Intellectual) \& } \\
\text { Creative }\end{array}$} & $\begin{array}{l}\text { DeBuse, } \\
\text { M. A. L. } \\
1990\end{array}$ & $\begin{array}{c}\text { William Gray's } \\
\text { 'Four-Phase Mentoring } \\
\text { Model', Oregon, USA }\end{array}$ & $\begin{array}{l}\text { Questionnaire-based survey } \\
\text { 1. Mentors }(\mathrm{N}=90) \\
\text { 2. Mentees }(\mathrm{N}=52) \\
\text { 3. Parents of Mentees } \\
(\mathrm{N}=37) \\
\text { 4. Able Learner Advocates } \\
(\mathrm{N}=7) \\
\text { 5. School Administrators } \\
(\mathrm{N}=7) \\
\text { 6. Regular Classroom } \\
\text { Teachers of Mentees } \\
(\mathrm{N}=26)\end{array}$ & $\begin{array}{l}\text { The study results were extremely positive. Mentors } \\
\text { mentioned that they experienced an improvement in their } \\
\text { ability to facilitate independent study and students } \\
\text { mentioned that they improved their } \\
\text { research/investigation skills. Both groups, mentors and } \\
\text { mentees, showed a positive attitude towards most aspects } \\
\text { of the mentoring program in which they were involved. } \\
\text { The results indicate that this type of mentoring program } \\
\text { is a promising approach both for meeting the } \\
\text { development/learning needs of students who are } \\
\text { preparing to become teachers, as well as those of middle } \\
\text { school talented students. }\end{array}$ \\
\hline & & $\begin{array}{l}\text { Templin, M. A., } \\
\text { Doran, R. L., } \\
\quad \& \\
\text { Engemann, J. F. } \\
\quad 1999 \\
\end{array}$ & $\begin{array}{l}\text { A University-Based Summer } \\
\text { Science Mentorship Program } \\
\text { Buffalo, New York, USA }\end{array}$ & $\begin{array}{l}\text { Interview-based survey } \\
\text { Mentees }(\mathrm{N}=8)\end{array}$ & $\begin{array}{l}\text { The results of the study indicated that mentors played a } \\
\text { crucial role in framing the participants experience and } \\
\text { influencing their affect and that careful selection and } \\
\text { timing of research projects was critical to participants' } \\
\text { attitude of learning and accomplishment. }\end{array}$ \\
\hline & & $\begin{array}{l}\text { Shevitz, B., } \\
\text { Weinfeld, R., } \\
\text { Jeweler, S., } \\
\text { \& } \\
\text { Barnes- } \\
\text { Robinson, L. } \\
2003\end{array}$ & $\begin{array}{c}\text { Wings Mentor Program } \\
\text { Division of Accelerated and } \\
\text { Enriched Instruction of Maryland's } \\
\text { Montgomery County Public Schools } \\
\text { USA }\end{array}$ & $\begin{array}{l}\text { Evaluations based on } \\
\text { Questionnaire-survey and } \\
\text { testimonies } \\
\text { Mentors, Students, Parents } \\
\text { of Students and Teachers } \\
\text { involved in the program }\end{array}$ & $\begin{array}{l}\text { The evaluations of the program have indicated an } \\
\text { improvement of students' self-concept, positively changes } \\
\text { other's perceptions of them and promotes their overall } \\
\text { motivation in the classroom. Also, according to parents of } \\
\text { talented students who have been involved in the } \\
\text { mentoring program Wings Mentor Program, no other } \\
\text { educational strategy has contributed to their children's } \\
\text { progress as the mentoring relationships established in this } \\
\text { program. }\end{array}$ \\
\hline & & $\begin{array}{l}\text { Manning, S. } \\
\quad 2005\end{array}$ & $\begin{array}{c}\text { Cross-Age Tutoring and Mentoring } \\
\text { Program }\end{array}$ & $\begin{array}{l}\text { Informal Observations and } \\
\text { Phonics Skills Assessments, } \\
\text { Method of } \\
\text { Ongoing Assessment } \\
\\
\text { Mentors, Students }\end{array}$ & $\begin{array}{l}\text { The informal evidence gathered using the cross-age } \\
\text { mentoring strategy revealed the development of } \\
\text { dispositions important to strong leadership. Information } \\
\text { and informal "evidence" about the implementation of the } \\
\text { proposed strategy for the mentoring program have } \\
\text { demonstrated the development of the most important } \\
\text { leadership dispositions among the talented students } \\
\text { involved in the program, such as: improving learning and } \\
\text { teaching skills, improving decision-making capacity, } \\
\text { increasing sensitivity to the needs of others, improvement } \\
\text { of the ability to solve problems, as well as the }\end{array}$ \\
\hline
\end{tabular}




\begin{tabular}{|c|c|c|c|c|}
\hline \multirow{4}{*}{$\begin{array}{l}\text { Academic, Cognitive } \\
\text { (Intellectual) \& } \\
\text { Creative }\end{array}$} & & & & $\begin{array}{l}\text { organizational and planning skills in approaching } \\
\text { project. The program implementation limit was, however } \\
\text { the age of participants; the author suggests that } \\
\text { implementing the program with older pupils would be } \\
\text { helpful in achieving more visible/good results. }\end{array}$ \\
\hline & $\begin{array}{c}\text { Castro, R. M.-F. } \\
2008\end{array}$ & $\begin{array}{l}\text { Peer and Mentoring Network for } \\
\text { Gifted } \\
\text { Underachieving Latino Students } \\
\text { Alexander Dumas High School } \\
\text { Los Angeles Unified School District } \\
\text { USA }\end{array}$ & $\begin{array}{c}\text { Quantitative and Qualitative } \\
\text { measures } \\
\text { Questionnaire-based survey } \\
\text { Interview-based survey } \\
\text { Reflections and Journals } \\
\text { Mentees ( } \mathrm{N}=23 \text { ) } \\
\text { (Gifted Underachieving } \\
\text { Latino high school students) }\end{array}$ & $\begin{array}{l}\text { The results of the study indicated that the students } \\
\text { grades, their academic work practices and their } \\
\text { cooperation skills, as described by their teachers, revealed } \\
\text { little statistically significant change following the } \\
\text { participation in the intervention and mentoring program } \\
\text { Moreover, the participants have demonstrated a } \\
\text { precarious knowledge of their own skills/talents, fact that } \\
\text { has contributed to their low self-expectations in terms of } \\
\text { their personal success. However, the students included in } \\
\text { the program mentioned that they had made changes in } \\
\text { their intellectual/learning behaviors in order to improve } \\
\text { their academic performance, which proved to be } \\
\text { statistically significant. In most cases, the results have } \\
\text { shown that the students and the mentors involved in the } \\
\text { program want to work together again. }\end{array}$ \\
\hline & $\begin{array}{l}\text { Mammadov, S., } \\
\quad \& \\
\text { TopÇu, A. } 2014\end{array}$ & $\begin{array}{c}\text { E-mentoring Project in } \\
\text { Mathematics } \\
\text { Private Middle School, Istanbul, } \\
\text { Turkey }\end{array}$ & $\begin{array}{l}\text { Interview-based survey } \\
\text { Mentees }(\mathrm{N}=5)\end{array}$ & $\begin{array}{l}\text { The study reported in this article investigated the role } \\
\text { of e-mentoring in gifted students' academic life. The study } \\
\text { results indicated that talented students who benefited } \\
\text { from e-mentoring project in mathematics showed a high } \\
\text { motivation, as well as the desire to maintain their } \\
\text { perseverance in fulfilling the individual and group tasks } \\
\text { that were assigned to them. The study also revealed that } \\
\text { the five talented students formed an effective and } \\
\text { interactive group and collaborated, finding a way to work } \\
\text { as a community. The results also showed that the fact that } \\
\text { talented students worked like professionals / in a } \\
\text { professional way helped them to think and act like real } \\
\text { mathematicians. }\end{array}$ \\
\hline & $\begin{array}{l}\text { Șahin, F. } \\
2014\end{array}$ & $\begin{array}{l}\text { Mentoring Program for developing } \\
\text { creative potential } \\
\text { Two different private schools } \\
\text { Thrace Region, Turkey }\end{array}$ & $\begin{array}{l}\text { Experimental design with } \\
\text { pre-test/post-test } \\
\text { control group } \\
\text { Questionnaire-based survey } \\
\\
\text { Mentees (N=91students, } \\
43 \text { of whom are gifted } \\
\text { and } 48 \text { are non-gifted) }\end{array}$ & $\begin{array}{l}\text { The scores obtained by the participants in the Torrance } \\
\text { Test of Creative Thinking, pre and post-test, showed an } \\
\text { increase in creative thinking skills among the participants } \\
\text { in both groups, without noticing a significant difference } \\
\text { between talented and non-talented students. Thereby } \\
\text { involvement in a mentoring relationship has proven to be } \\
\text { extremely effective in improving the creative abilities of } \\
\text { both groups, talented students and non-talented students. }\end{array}$ \\
\hline
\end{tabular}




\begin{tabular}{|c|c|c|c|c|}
\hline \multirow{3}{*}{$\begin{array}{l}\text { Academic, Cognitive } \\
\text { (Intellectual) \& } \\
\text { Creative }\end{array}$} & $\begin{array}{l}\text { Besnoy, K. D., \& } \\
\text { McDaniel, S. C. } \\
2016\end{array}$ & $\begin{array}{c}\text { Crimson G.U.I.D.E. (Going Up In } \\
\text { Dreams and Esteem) Program } \\
\text { (the cross-age mentoring model) } \\
\text { USA }\end{array}$ & $\begin{array}{l}\text { Questionnaire-based survey } \\
\text { Mentors }(\mathrm{N}=6) \\
\text { Mentees }(\mathrm{N}=11)\end{array}$ & $\begin{array}{l}\text { The results of the program implementation revealed } \\
\text { that: coordinators of the mentoring program mentioned } \\
\text { that they have a better knowledge of the talented students } \\
\text { special needs after this project; the mentoring program } \\
\text { brought benefits for the development of leadership skills } \\
\text { among talented students, and the fact that the Crimson } \\
\text { GUIDE mentoring program can be a very good starting } \\
\text { point for future attempts to implement similar mentoring } \\
\text { programs that place the talented student in the mentor } \\
\text { role, not just in the mentee role. }\end{array}$ \\
\hline & $\begin{array}{l}\text { Zorman, R., } \\
\text { Rachmel, S., } \\
\quad \& \\
\text { Bashan, Z. } \\
2016\end{array}$ & $\begin{array}{l}\text { National Mentoring Program } \\
\text { Division for Gifted and Outstanding } \\
\text { Students in the Ministry of } \\
\text { Education of Israel, Szold Institute }\end{array}$ & $\begin{array}{l}\text { Formative Evaluation } \\
\text { Interview-based survey } \\
\text { Mentees }(\mathrm{N}=50)\end{array}$ & $\begin{array}{l}\text { The goal of the program was to cultivate future leaders } \\
\text { in various talent areas. A total of } 50 \text { out of } 53 \text { young } \\
\text { scholars, constituting } 94 \% \text { of the young scholars, } \\
\text { completed the program. Each of the } 50 \text { students who } \\
\text { completed the first three cohorts of the program produced } \\
\text { high quality university level work. Nearly half }(42 \%) \text { of the } \\
\text { young scholars engaged in activities and/or completed } \\
\text { projects which received significant recognition of their } \\
\text { work from the professional community in their field of } \\
\text { interest, as well as the publication of their works at various } \\
\text { conferences. }\end{array}$ \\
\hline & $\begin{array}{c}\text { Alhanaya, M. } \\
2020\end{array}$ & $\begin{array}{c}\text { University-Based Gifted Mentorship } \\
\text { Program } \\
\text { Future Researcher Program (FRP) } \\
\text { Five Governmental Universities } \\
\text { Kingdom of Saudi Arabia }\end{array}$ & $\begin{array}{l}\text { Mixed-Method Approach } \\
\text { Questionnaire-based survey } \\
\text { Interview-based survey } \\
\text { Reflections and Journals } \\
\text { Mentors }(\mathrm{N}=60) \\
\text { Mentees }(\mathrm{N}=100)\end{array}$ & $\begin{array}{l}\text { Students involved in the program perceived } \\
\text { improvement in their cognitive and research skills, as a } \\
\text { result of their participation in the mentoring program; } \\
\text { through its challenging independent studies curricula, } \\
\text { which were based on student interests and conducted in } \\
\text { an academic setting under the supervision of experts. } \\
\text { Interview responses indicated that perhaps the most } \\
\text { important component of an enrichment program may be } \\
\text { the university mentors themselves, which provide } \\
\text { students valuable direct guidance and serve as a model for } \\
\text { professional achievement. }\end{array}$ \\
\hline $\begin{array}{l}\text { Psychosocial, } \\
\text { Socioemotional or } \\
\text { Affective }\end{array}$ & $\begin{array}{cc}\text { Cooper, } & \text { D. } \\
\text { L. } & \\
1991 & \end{array}$ & $\begin{array}{l}\text { Mississippi School for Mathematics } \\
\text { and Science (MSMS), } \\
\text { Columbus, USA. }\end{array}$ & $\begin{array}{c}\text { Multiple-case study } \\
\text { (Structured interviews) } \\
\text { Mentees }(\mathrm{N}=6) \\
\text { (Six high school students) }\end{array}$ & $\begin{array}{l}\text { The study analyzed the mentoring relationship between } \\
\text { talented students and their mentors, with the aim that } \\
\text { teachers and educational counselors who play the role of } \\
\text { mentor for these students to meet their specific needs in a } \\
\text { better / efficient way. All subjects who participated in the } \\
\text { research mentioned that the initial attraction towards } \\
\text { their potential mentors was based on perceiving them } \\
\text { being open to mentoring and guidance, as well as having a } \\
\text { good capacity to establish effective inter-human } \\
\text { connections. All mentoring relationships have been }\end{array}$ \\
\hline
\end{tabular}




\begin{tabular}{|c|c|c|c|c|}
\hline \multirow{3}{*}{$\begin{array}{l}\text { Psychosocial, } \\
\text { Socioemotional or } \\
\text { Affective }\end{array}$} & & & & $\begin{array}{l}\text { established in the context in which subjects faced the } \\
\text { feeling of social isolation. This indicates that the mentoring } \\
\text { relationship offered to students a sense of acceptance and } \\
\text { support in their need to establish relationships with adults } \\
\text { who have the same interests as them. Also, the subjects } \\
\text { declare that the mentoring relationship provide them } \\
\text { support, encouragement, trust and the feeling they were } \\
\text { being related to. }\end{array}$ \\
\hline & $\begin{array}{l}\text { Hébert, T. P., \& } \\
\text { Olenchak, F. R. } \\
\quad 2000\end{array}$ & USA & $\begin{array}{l}\text { A comparative case study } \\
\text { research design } \\
\text { (A combination of semi- } \\
\text { structured interviews and } \\
\text { document } \\
\text { review) } \\
\text { Mentees ( } \mathrm{N}=3)\end{array}$ & $\begin{array}{l}\text { The study analyzed the mentorship experiences of three } \\
\text { males students who demonstrated various features of } \\
\text { giftedness and underachievement. The results of the study } \\
\text { indicate that for this category of talented students } \\
\text { (underachievers) the influence of a significant adult on a } \\
\text { young person is very important; because their mentors } \\
\text { were open-minded and nonjudgmental, provide them } \\
\text { consistent and personalized social/emotional support and } \\
\text { advocacy; and applied strength and interest based } \\
\text { strategies for intervention to reverse their } \\
\text { underachievement. }\end{array}$ \\
\hline & $\begin{array}{l}\text { Irving, S. E., } \\
\text { Moore, D. W., } \\
\& \\
\text { Hamilton, R. J. } \\
2003\end{array}$ & $\begin{array}{l}\text { Pohutukawa Mentoring Program } \\
\text { Pohutukawa College, Auckland, } \\
\text { New Zealand }\end{array}$ & $\begin{array}{l}\text { Questionnaire-based survey } \\
\text { Interview-based survey } \\
\text { Mentees }(\mathrm{N}=62)\end{array}$ & $\begin{array}{l}\text { The results of a study carried out following the } \\
\text { implementation of the mentoring program Pohutukawa } \\
\text { showed that it had positive effects on affective } \\
\text { development of talented students but did not have a } \\
\text { significant impact on their academic performance. The } \\
\text { positive effects of this mentoring program on talented } \\
\text { students include increasing confidence and improving } \\
\text { their ability to approach an exam/an academic } \\
\text { examination. The students included in this mentoring } \\
\text { program have been guided by honorable members of the } \\
\text { high school teaching staff at a time in their lives when } \\
\text { many teenagers are deprived of contact with an adult that } \\
\text { can guide them. This fact has added a human dimension to } \\
\text { their development as young talented students with great } \\
\text { potential, also giving them the opportunity to take control } \\
\text { over their own learning process. However, the program } \\
\text { failed to provide a mechanism for improving the academic } \\
\text { performance of the students who have been } \\
\text { mentored/guided; it remains to be seen if any changes to } \\
\text { the program itself or to its objectives will lead to this } \\
\text { desired purpose. }\end{array}$ \\
\hline
\end{tabular}




\begin{tabular}{|c|c|c|c|c|}
\hline \multirow[b]{2}{*}{$\begin{array}{l}\text { Psychosocial, } \\
\text { Socioemotional or } \\
\text { Affective }\end{array}$} & $\begin{array}{c}\text { Demirhan, E. } \\
2018\end{array}$ & $\begin{array}{c}\text { Nature Education Program Based } \\
\text { on a Mentoring Approach } \\
\text { Turkey }\end{array}$ & $\begin{array}{l}\text { Qualitative measures } \\
\text { Case Study Pattern } \\
\text { Open-ended Questions and } \\
\text { Diaries } \\
\text { Mentors }(\mathrm{N}=16) \\
\text { Mentees }(\mathrm{N}=16)\end{array}$ & $\begin{array}{l}\text { The study results indicated the importance of social gains } \\
\text { of the mentoring program participants. Both, teachers and } \\
\text { students involved in the program reported positive } \\
\text { feelings (happy, lucky, proud, fun, beneficial for both } \\
\text { parties, realizing weaknesses, learning new information) } \\
\text { regarding the project. These findings also indicate that the } \\
\text { prospective teachers feel positive about taking part in the } \\
\text { project together with gifted students. }\end{array}$ \\
\hline & $\begin{array}{l}\text { Chan, L. K., } \\
\text { Chan, D. W., } \\
\text { \& } \\
\text { Sun, X. } \\
2020\end{array}$ & $\begin{array}{l}\text { Gifted Peer Mentoring Scheme } \\
\text { Chinese University of Hong Kong }\end{array}$ & $\begin{array}{l}\text { Quantitative and Qualitative } \\
\text { measures } \\
\text { Questionnaire-based survey } \\
\text { Personal Reflective Diaries } \\
\text { Reflection Journals } \\
\text { Semi-structured Focus } \\
\text { Group Interviews }\end{array}$ & $\begin{array}{l}\text { Findings of program evaluation, for 2016, revealed the } \\
\text { concurrently positive development in both the mentors } \\
\text { and the mentees of the Gifted Peer Mentoring Scheme and } \\
\text { confirmed the positive impacts on psychological well- } \\
\text { being among gifted and talented students. The results } \\
\text { indicated, also, that the learning needs of gifted mentees } \\
\text { were well addressed through their active participation, } \\
\text { self-reflection, and interaction with peers and the serving } \\
\text { group. The Scheme provided gifted mentors and mentees } \\
\text { with multiple opportunities for psychosocial and personal } \\
\text { skills development, including higher level of } \\
\text { selfunderstanding, self-confidence, willingness to connect } \\
\text { and share with gifted peers, tolerance and appreciation of } \\
\text { others, acceptance to new challenges and better } \\
\text { communication and interpersonal skills. }\end{array}$ \\
\hline \multirow{2}{*}{$\begin{array}{l}\text { Academic, Cognitive } \\
\text { (Intellectual) \& } \\
\text { Creative, } \\
\text { Psychosocial, } \\
\text { Socioemotional or } \\
\text { Affective, Career or } \\
\text { Vocational support }\end{array}$} & $\begin{array}{c}\text { Ambrose, D., } \\
\text { Allen, J., \& } \\
\text { Huntley, S. } 1994\end{array}$ & Georgia, USA & $\begin{array}{l}\text { Retrospective case study } \\
\text { (based on a questionnaire } \\
\text { and an interview) } \\
\text { Mentors }(\mathrm{N}=2) \\
\text { Mentees }(\mathrm{N}=1)\end{array}$ & $\begin{array}{l}\text { In the research, the influence of the two mentors on } \\
\text { John's cognitive and affective development was analyzed. } \\
\text { The results obtained have shown that the mentoring } \\
\text { relationship helped John, a young talented artist,, to } \\
\text { consolidate his thinking style, to develop his metacognitive } \\
\text { skills and to develop and fortify his career options, } \\
\text { providing him, at the same time, emotional support when } \\
\text { he most needed it. }\end{array}$ \\
\hline & $\begin{array}{l}\text { Davalos, R. A., } \\
\text { \& } \\
\text { Haensly, P. A. } \\
1997\end{array}$ & $\begin{array}{c}\text { Independent } \\
\text { Study/Mentorship course (ISM) } \\
\text { USA }\end{array}$ & $\begin{array}{l}\text { Questionnaire-based survey } \\
\text { Mentees }(\mathrm{N}=90)\end{array}$ & $\begin{array}{l}\text { The study analyzed the possible benefits of mentoring } \\
\text { for gifted students. Subjects who participated in the } \\
\text { research mentioned the following benefits of the } \\
\text { mentoring relationship, related to how they perceived the } \\
\text { experience of independent study/mentorship during their } \\
\text { school years: an improvement in their self-esteem or self- } \\
\text { concept ( } 47 \%) \text {; the personal significance of the mentor to } \\
\text { the student - eg. as guide, as friend, as role model ( } 45 \%) \text {; } \\
\text { the value of career exploration ( } 33 \%) \text {; the growth of their } \\
\text { work skills - improvements in organization, time } \\
\text { management, and responsibility }(24 \%) \text {; the mentors as }\end{array}$ \\
\hline
\end{tabular}




\begin{tabular}{|c|c|c|c|c|}
\hline \multirow{4}{*}{$\begin{array}{l}\text { Academic, Cognitive } \\
\text { (Intellectual) \& } \\
\text { Creative, } \\
\text { Psychosocial, } \\
\text { Socioemotional or } \\
\text { Affective, } \\
\text { Career or Vocational } \\
\text { support }\end{array}$} & & & & $\begin{array}{l}\text { sources for "real life" learning (24\%); the help offered for } \\
\text { college preparation - improved thinking skills/problem } \\
\text { solving abilities (19\%). }\end{array}$ \\
\hline & & & & \\
\hline & $\begin{array}{l}\text { Little, C. A., } \\
\text { Kearney, K. L, } \\
\text { \& } \\
\text { Britner, P. A. } \\
2010\end{array}$ & $\begin{array}{c}\text { Summer Mentoring Program } \\
\text { USA }\end{array}$ & $\begin{array}{l}\text { Questionnaire-based survey } \\
\qquad \begin{array}{c}\text { \& } \\
\text { Journal Questions }\end{array} \\
\text { Mentees }(\mathrm{N}=72)\end{array}$ & $\begin{array}{l}\text { The research results revealed a difference in the way } \\
\text { participants perceive their own research skills and their } \\
\text { own competence for getting a job, in the sense that they } \\
\text { mentioned an improvement after participating in the } \\
\text { mentoring program. At the same time, the talented } \\
\text { students said that they had positive and constructive } \\
\text { relationships with their mentors, especially when they felt } \\
\text { that their mentors were reserving their time to guide them, } \\
\text { being friendly and approachable. }\end{array}$ \\
\hline & $\begin{array}{l}\text { Ibáñez García, } \\
\text { et. all } \\
2020\end{array}$ & $\begin{array}{l}\text { GuíaMe-AC-UMA } \\
\text { Programme } \\
\text { Amentúrate programme } \\
\text { Málaga, Cantabria, Spain }\end{array}$ & $\begin{array}{l}\text { Questionnaire-based survey } \\
\text { Mentors (N=39: N=25)) } \\
\text { Mentees (N=130; }=41 \text { ) } \\
\text { Technical-Research Team } \\
\text { (N=9; } N=11)\end{array}$ & $\begin{array}{l}\text { The results of the study indicated a high level of } \\
\text { satisfaction with the development of the workshops } \\
\text { offered by both mentoring programmes, on the part of all } \\
\text { participants. Furthermore, both universities the } \\
\text { workshops aim to satisfy the needs of the mentees at a } \\
\text { cognitive level. The workshops try to take students out of } \\
\text { their comfort zone, allowing them to fully develop their } \\
\text { potential, performing tasks that pose a challenge, and } \\
\text { creating an environment that supports their e } \\
\text { orts and acknowledges their successes. }\end{array}$ \\
\hline
\end{tabular}

Table 1 Mentoring Programs for Talented Students 


\section{Results}

A total of 19 papers (articles and dissertations), that met our inclusion criteria, were investigated in the review. Ten of these focused on the relationship between mentoring programs and their impact on the development of talented students at academic, cognitive (intellectual) \& creative level, five of these focused on the relationship between mentoring programs and their impact on the development of talented students at the psychosocial, socioemotional or affective level and four of these focused on the relationship between mentoring programs and their impact on the development of talented students at all three levels: academic, cognitive (intellectual) \& creative, psychosocial, socioemotional or affective and career or vocational support. The number of participants in these studies varied between a total of 221 participants (mentors, mentees, parents of mentees, able learner advocates, school administrators and regular classroom teachers of mentees) to 3 participants (mentors and mentees). The mentoring programs for talented students that we identified are quite diverse, in terms of organization and from the point of view of the objectives they aim to support talented students in their own process of development; but the results of the review indicated that all of them are perceived as very useful by the participants. In the literature, the mentoring relationship is presented as an educational alternative for talented students/ students with high abilities, in order to maximize their potential. Therefore, mentoring is considered to be an educational alternative that gets a lot of benefits for talented students/ students with high abilities, especially in the context of the dissatisfaction and monotony which they experience during classes, in the traditional education system. The mentoring relationship offers talented students the opportunity to deeply explore their passion and preoccupation for a specific area of interest, also giving them more control over their own learning process. In order that schools and high schools to be able to implement as many mentoring programs as possible, their involvement in the research of mentoring and its benefits for talented students/ students with high abilities is absolutely necessary (Bisland, 2001).

Burton (2012), also, conducted a comprehensive systematic review of the relevant literature, in which he analyzed the mentoring relationship as a way of ensuring appropriate intellectual and socio-emotional development for talented students/students with high abilities, in relation to their formation/education in alternative learning environments. Research in the field has also demonstrated that care and emotional/affective support between children and adults who are not members of their family are vital for the proper development of the children; as well as the fact that mentoring relationship can be a major benefit for any child (Lunsford, 2011). Moreover, related to talented students, research has shown that involvement in a mentoring relationship is extremely important, the benefits of mentoring on their development being unique because of their special characteristics (DuBois, Holloway, Valentine, \& Cooper, 2002). That is why it is very important that experts and researchers in the field of education take action for promoting mentoring as a proper manner of supporting 
talented students in their cognitive and socio-emotional development. They can do this by supporting the implementation, extension and consolidation of formal mentoring programs for talented students and students with high abilities, and also by removing barriers (both implicit and explicit) in the natural formation of mentoring relationships between talented students and adults who are already important figures in their lives.

Several studies have already demonstrated that mentoring is very important and can help talented students become specialists and remarkable exponents of their fields of interest (Lunsford, 2011). The students' participating in mentoring programs success in identifying career options and choosing a vocation depends on the quality of their relationship with the mentor. At the same time, it has become clear that the mentoring relationship can be an extremely useful experience for the training and development of talented students. It is important to realize, however, that this relationship is reciprocal. While the mentor offers development opportunities and experience, as well as access to professional networks, the mentee must be motivated, curious and interested in his or her field of study, in order for the mentoring relationship to develop into a high quality relationship. Focusing on the real psychological needs of talented students within the mentoring relationship could help improve mentoring opportunities (Lunsford, 2011).

Based on the study results conducted by Cooper (1991), a series of recommendations have been made for specialized staff (teachers, school counselors, psychologists) who work with talented students, for improving their activity as mentors for this category of school population, as follows:

1. Talented students want to establish relationships with adults who share their interests /passions outside the school/academic context. Teachers and school counselors who are working with them should be available for this kind of activities.

2. In the professional relationship with talented students, teachers and school counselors should be sincere and really interested in mentoring them, in order to make their work really successful.

3. Teachers and school counselors who work with talented students should have knowledge about the special characteristics of these students, like perfectionism and fear of failure, in order to help them accept both, success and failure.

4. Teachers and school counselors should have the ability to manage frustration, anger and revolt frequently manifested by talented students. They are not perfect.

5 . Teachers and school counselors who work with talented students should have specific skills, such as providing guidance to their mentee in time management. Talented students who get high grades without learning will never know how to effectively manage their working time.

\section{Conclusions and discussions}

The present paper was based on the premise that talented students represent a special category of pupils with specific psycho-behavioral characteristics and needs that require specialized educational interventions in order to fully develop their abilities and to 
maximize their potential. In the school context, one of the most appropriate interventions for this is mentoring, fact that was also demonstrated by a series of studies that underline its positive effects on the development of this special category of students, on the psychosocial and cognitive level, as well as on career orientation (Casey, 1997, Clasen\&Clasen, 2003).

In the field of gifted education mentoring is still rarely used and there is no systematic approach to this kind of activity (Grassinger, Porath, \& Ziegler, 2010). The mentoring programs analyzed by us are quite diverse and have been implemented in various geographical areas, therefore we believe that the impact of their implementation on the development of talented students may be relevant to underline the importance of such initiatives, in general, in national educational systems. This is why, the studies selected and presented by us in this regard describe a series of mentoring programs especially designed for talented students, which have contributed to their development, fact that proves the benefits and the impact of the involvement of these students in a mentoring relationship and the necessity for this type of programs to be sustained in an educational context, not only at an informal level but also through formal programs specifically designed and implemented for this purpose. The mentoring programs presented can represent examples of good practice for educational policy makers, in order to think of a coherent strategy to support talented students, at national level; but, also, can be implemented by school principals, at the local level, depending on the specific needs of the talented students they work with, in their institutions, and the resources available.

Therefore, based on the results of the studies included in our narrative review, we can conclude that: 1 . It is recommended to introduce special mentoring programs for talented students in schools in order to offer them the moral and emotional support that they need, but also for cognitive stimulation; 2. In the field of gifted education there is not an "extensive" mentoring program which should be considered suitable for each child or school, not even one that has been implemented at the level of several institutions; but a series of alternatives that can be chosen, depending on the particular needs of the talented students you work with and the cultural specificity; 3 . The mentoring programs can take the form of research projects in which talented students can work with their teachers on researching topics of common interest and then present their works as part of an event/strategy of promoting talents; 4 . The mentoring programs for talented students can include various activities, such as: additional training sessions for improving academic performance; exploring the student's areas of interest, in order to choose the right career path; informal discussions regarding appropriate strategies for managing different social and emotional difficulties; 5. Although the involvement of talented students in a mentoring program does not always lead to a considerable improvement of their academic results, participants note the positive impact of mentoring on their social and emotional development. This fact can be very important and useful especially in the educational systems where talented students are trained in the public or general educational system and do not benefit from other educational interventions, to provide 
them the support they need to integrate and to maximize their potential; 6. For twiceexceptional students, that are facing school underachievement or come from disadvantaged backgrounds and are unaware of their own potential and incapable of using it without specific interventions, mentoring is one of the best strategies to make them less vulnerable to sacrificing their potential and their talents before graduating; 7 . Within a mentoring program talented students can also play the role of the mentor in order to develop their leadership skills and also to help their younger colleagues.

As for the limitations of our research, it is necessary to report the difficulty of accessing some of the international databases. In most of the cases, access was only possible in the institutions themselves, or by paying for the article. Thereby, the difficulty of retrieving relevant journal articles is a limitation of our search for data. The studies presented here are more related to the researchers' possibilities of access to studies than a quantity existing in the search period. It is also important to consider the fact that mentoring programs for talented students, described in the literature, are also quite diverse; in terms of organization and from the point of view of the objectives they aim to support talented students in their own process of development - focusing on the academic, cognitive (intellectual) area; or on the creative, psychosocial, socioemotional and affective one, or on the career and vocational support. Therefore, the fact that only electronic databases have been consulted needs to be considered, and also the fact that mentoring programs for talented students are not, so far, systematically approached in the literature. In this perspective, a suggestion for future studies is to conduct a specific, comprehensive and detailed research about how this topic - the subject of mentoring programs (for students) - has been approached in general education, compared with gifted education.

\section{References}

Alhanaya, M. (2020). Reflecting on the role of mentorship in gifted education: Mixed approach study. Journal for the Education of Gifted Young Scientists, 8(3), 1261-1274.

Ambrose, D., Allen, J., \& Huntley, S. (1994). Mentorship of the highly creative. Roper Review, 17 (2).

Besnoy, K. D., \& McDaniel, S. C. (2016). Going Up in Dreams and Esteem Cross-Age Mentoring to Promote Leadership Skills in High School-Age Gifted Students. Gifted Child Today, 39 (1), 18-30.

Bisland, A. (2001). Mentoring: An educational alternative for gifted students. Gifted Child Today, (24) 4, 22-25, 64.

Bloom, B. S. (Ed.). (1985a). Developing talent in young people. New York, NY: Ballantine.

Burton, J. (2012). Mentoring as an academic and socio-emotional provision for gifted children: A research review and case study. The second of three papers on the topic of Nurturing Giftedness in Alternative Learning Environments presented at the 12th Asia-Pacific Conference on Giftedness Dubai. United Arab Emirates, 14-18 July 2012.

Cakir, L., \& Kocabas, I. (2016). Mentoring in Gifted Student's Education and a Model Suggestion. Educational Process: International Journal, 5(1), 76-90.

Casey, K. M. A. (1997). The Particular Value of Mentorships for Gifted Students - Dissertation. McGill University (Canada), United States.

Casey, K. M. A., \& Shore, Bruce M. (2000). Mentors contributions to gifted adolescents' affective, social, and vocational development. Roeper Review, 22 (4), 227-230. 
Castro, R. M.-F. (2008). Establishing a peer and mentoring network to support achievement as an intervention for underachieving gifted Latino high school students - Dissertation. University of California: United States, Los Angeles.

Chan, L. K., Chan, D. W., \& Sun, X. (2020). University-based gifted programs for gifted and talented students in Hong Kong: Practice and evaluation. Gifted Education International, 36(2), 90-107.

Clasen, D. R., \& Clasen, R. E. (2003). Mentoring the gifted and talented. Handbook of gifted education 3rd edition. Boston: Allyn and Bacon.

Cooper, D. L. (1991). Case studies of mentors and gifted high school students: The role of the relationship in academic and emotional success - Dissertation. United States: Mississippi State University.

Council of Europe - Committee on Culture and Education (1994). Recommandation 1248 on education for gifted children.

Crețu, C. (1995-1996). Surveys of romanian training and practices in the gifted and talented education. Analele științifice ale Universității "Alexandru Ioan Cuza" din Iași (serie nouă) Psihologie-Științele Educației, Tom. IV-V, Iași: Editura Universității "Alexandru Ioan Cuza".

Crețu, C. (1995). Politica promovării talentelor: dreptul la o educație diferențiată. Iași: Editura Cronica.

Crețu, C., \& Rogoz, N. (2016). The dynamic of study mobility motivation among highly able students from high schools and universities. In 15th International ECHA Conference - "TALENTS IN MOTION" Encouraging the Gifted in the context of Migration and Intercultural Exchange, March 2-5, 2016, Vienna, Austria - www.echa2016.info (Date and time of accessing: 23.05.2016, 12:40).

Davalos, R. A., \& Haensly, P. A. (1997). After the dust has settled: Youth reflect on their high school mentored research experience. Roeper Review, 19(4), 204-207.

DeBuse, M. A. L. (1990), Implementation and evaluation of a university-based mentor-assisted enrichment program for talented and gifted middle school students - Dissertation, United States, University of Oregon.

Demirhan, E. (2018). Opinions of Gifted Students and Prospective Teachers on Nature Education Program Based on Mentoring Approach. Inonu University Journal of the Faculty of Education (INUJFE), 19(3).

DuBois, D. L., Holloway, B. E., Valentine, J. C., \& Cooper, H. (2002). Effectiveness of mentoring programs for youth: A meta-analytic review. American journal of community psychology, 30(2), 157-197.

Eurydice (2006). Mesures éducatives spécifiques pour la promotion de tous les talents en Europe Document de travail. Brussels, Belgium.

Gagné, F. (1985). Giftedness and talent: Reexamining a reexamination of the definitions. Gifted child quarterly, 29(3), 103-112.

Goff, K., \& Torrance, E. P. (1999). Discovering and developing giftedness through mentoring. Gifted Child Today Magazine, 22 (3), 14-15, 52-53.

Grassinger, R., Porath, M., \& Ziegler, A. (2010). Mentoring the gifted: A conceptual analysis. High Ability Studies, 21(1), 27-46.

Hébert, T. P., \& Olenchak, F. R. (2000). Mentors for gifted underachieving males: Developing potential and realizing promise. Gifted Child Quarterly, 44(3), 196-207.

Ibáñez García, A., Gallego Álvarez, T., García Román, M., Guillén Martín, V. M., Tomé Merchán, D., \& Castro Zamudio, S. (2020). University Mentoring Programmes for Gifted High School Students: Satisfaction of Workshops. Sustainability, 12(13), 5282.

Irving, S. E., Moore, D. W., \& Hamilton, R. J. (2003). Mentoring for high ability high school students. In Education \& Training, Vol. 45.

Kaufman, F. A., Harrel, G., Milam, C. P., Woolverton, N., Miller, J. (1986). The nature, role, and influence of mentors in the lives of gifted adults. Journal of Counseling \& Development, 64, 576-578.

Kay, D., \& Hinds, R. (2002). A practical guide to mentoring. Oxford: How to Books.

Kram, K. E. (1985). Mentoring at work: Developmental relationships in organizational life. Glenview, IL: Scott, Foresman and Company. 
Little, C. A., Kearney, K. L, \& Britner, P. A. (2010). Students' Self-Concept and Perceptions of Mentoring Relationships in a Summer Mentorship Program for Talented Adolescents. Roeper Review, 32 (3), 189-199.

Lunsford, G. L. (2011). Psychology of Mentoring: The Case of Talented College Students. Journal of Advanced Academics, 22 (3), 474 - 498.

Mammadov, S., \& TopÇu, A. (2014). The Role of E-Mentoring in Mathematically Gifted Students' Academic Life: A Case Study. Journal for the Education of the Gifted, 37(3), 220 - 244.

Manning, S. (2005). Young Leaders: Growing Through Mentoring. Gifted Child Today, 28 (1), 14-20.

McBee, M. T., \& Makel, M. C. (2019). The quantitative implications of definitions of giftedness. AERA Open, 5(1), 2332858419831007.

Ritchotte, J. A., Suhr, D., Alfurayh, N. F., \& Graefe, A. K. (2016). An exploration of the psychosocial characteristics of high achieving students and identified gifted students: Implications for practice. Journal of Advanced Academics, 27(1), 23-38.

Roche, G. (1979). Much ado about mentors. Harvard Business Review, 57, 14-28.

Shevitz, B., Weinfeld, R., Jeweler, S., \& Barnes-Robinson, L. (2003). Mentoring empowers gifted/learning disabled students to soar!. Roeper Review, 26 (1), 37 - 40.

Sahin, F. (2014). The effectiveness of mentoring strategy for developing the creative potential of the gifted and non-gifted students. Thinking Skills and Creativity, 14, 47-55.

Subotnik, R. F., Olszewski-Kubilius, P., Khalid, M., \& Finster, H. (2021). A developmental view of mentoring talented students in academic and nonacademic domains. Annals of the New York Academy of Sciences, 1483(1), 199-207.

Templin, M. A., Doran, R. L., \& Engemann, J. F. (1999). A locally based science mentorship program for high achieving students: Unearthing issues that influence affective outcomes. School Science and Mathematics, 99(4), 205-213.

Torrance, E. P. (1984). Mentor relationships: How they aid creative achievement, endure, change, and die. Buffalo, NY: Bearly.

Vaillant, G. (1977). Adaptation to life. Boston, MA: Little-Brown.

Wright - Romjue, M. K. (1991). Highly Gifted Students' Participation in Mentoring Program - Dissertation. United States: University of Nebraska.

Zorman, R., Rachmel, S., \& Bashan, Z. (2016). The national mentoring program in Israel - Challenges and achievements. Gifted Education International, 32(2), 173-184. 